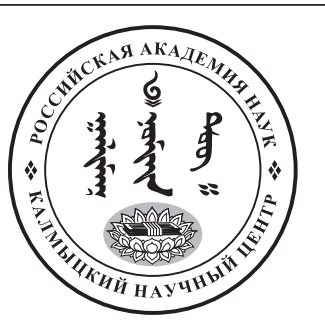

Published in the Russian Federation

Oriental Studies (Previous Name: Bulletin of the Kalmyk Institute

for Humanities of the Russian Academy of Sciences)

Has been issued as a journal since 2008

ISSN: 2619-0990; E-ISSN: 2619-1008

Vol. 14, Is. 3, pp. 469-478, 2021

Journal homepage: https://kigiran.elpub.ru

УДК / UDC 94(47).084.8

DOI: $10.22162 / 2619-0990-2021-55-3-469-478$

\title{
Крымский период жизни Басана Городовикова
}

\author{
Владимир Евгеньевич Поляков ${ }^{1}$
}

${ }^{1}$ Крымский инженерно-педагогический университет имени Февзи Якубова (д. 8, пер. Учебный, 295018 Симферополь, Российская Федерация)

доктор исторических наук, доцент, профессор кафедры истории

iD 0000-0003-1420-6459. E-mail: turahu@inbox.ru

(C) КалмНЦ РАН, 2021

(C) Поляков В. Е., 2021

Аннотация. Введение. Статья посвящена малоизученному, но очень яркому и насыщенному драматическими событиями крымскому периоду жизни крупного военного и политического деятеля Калмыкии, Героя Советского Союза Басана Бадьминовича Городовикова с августа 1941 г. по июнь 1942 г. Цель - описать и проанализировать крымский период в биографии Б. Б. Городовикова. Материаль и методы. В ходе исследования автор использовал широкий круг архивных материалов, а также мемуары участников партизанского движения в Крыму (в том числе неопубликованные). Результаты. Автор в ходе исследования описал участие полка Басана Городовикова в первых боях на севере Крыма, его отступление в горы и переход к партизанам, создание партизанского отряда и его действия в тылу врага. Активная деятельность отряда Б. Б. Городовикова показана на фоне объективной картины организации партизанского движения в Крыму. В статье раскрывается специфичность условий борьбы на полуострове. Прослежена роль военнослужащих, особенно на первом этапе партизанской борьбы, показаны сложности взаимоотношений командного состава 48-й кавдивизии и руководства партизанским движением в Крыму. Впервые документально освещена история награждения Б. Б. Городовикова орденом Красного Знамени, что явилось первым награждением крымских партизан. Детально отслежена драматическая история его эвакуации из партизанского леса на «Большую землю». Ряд неизвестных ранее документов и материалов введен в научный оборот впервые. Полученные результаты позволили прийти к выводу, что крымский период жизни Басана Городовикова был одним из самых драматичных в его жизни. В трудный для Крыма период он стал командиром одного из самых успешных партизанских отрядов, который после его эвакуации официально стал носить имя первого командира. Примечательно, что Басан Городовиков в числе первых крымских партизан был награжден боевым орденом, повышен в звании и в должности.

Ключевые слова: Великая Отечественная война 1941-1945 гг., Красная армия, Крым, Калмыкия, партизаны, Басан Городовиков, Мокроусов, крымские татары

Для цитирования: Поляков В. Е. Крымский период жизни Басана Городовикова // Oriental Studies. 2021. T. 14. № 3. C. 469-478. DOI: 10.22162/2619-0990-2021-55-3-469-478 


\title{
The Crimean Period in the Life of Basan Gorodovikov
}

\author{
Vladimir E. Polyakov ${ }^{1}$
}

${ }^{1}$ Fevzi Yakubov Crimean Engineering and Pedagogical University (8 Uchebnyi alley, 295018 Simferopol, Russian Federation)

Dr. Sc. (History), Associate Professor, Professor

iD 0000-0003-1420-6459. E-mail: turahu@inbox.ru

\author{
(C) KalmSC RAS, 2021 \\ (C) Polyakov V. E., 2021
}

\begin{abstract}
Introduction. The article deals with the Crimean period (August 1941 - June 1942) in the life of Basan Badminovich Gorodovikov, Hero of the Soviet Union and a major military and political figure of Kalmykia. The present article aims at describing and analyzing this less-known period of his biography, which was significant and full of dramatic events. Data and research methods. For the purposes of this research, the author has used a wide range of archival materials, as well as memoirs of participants of the partisan movement in the Crimea (including unpublished papers). Results. The author describes the first battles in the north of the Crimea in which Gorodovikov's regiment was engaged; then, its retreat into the mountains and transition to partisans, the creation of a partisan detachment and the actions behind enemy lines. The activities of Gorodovikov's detachment are shown against the general background of the partisan movement in the Crimea; special attention given to the discussion of warfare under the specific conditions on the peninsula. The article focuses on the role of the military personnel, especially at the first stage of the partisan movement, revealing, among other things, the problems in the relationship between the command staff of the $48^{\text {th }}$ cavalry division and the partisan leaders in the Crimea. For the first time, the article sheds light on the history of awarding Gorodovikov with the Order of the Red Banner, which was the first award of the Crimean partisans. The dramatic story of his evacuation from the partisan forest to the "Bol'shaia zemlia" is also documented in detail; with previously unknown documents and materials introduced in this paper. The undertaken research allows to conclude that the Crimean period in the life of Gorodovikov was one of the most dramatic in his biography. During a difficult period for the Crimea, he became the commander of one of the most successful partisan detachments, which after he left was officially named after him, its first commander. Notably, Gorodovikov was among the first Crimean partisans to be awarded a military order and to get a promotion in rank and in office.

Keywords: Great Patriotic War of 1941-1945, Red Army, Crimea, Kalmykia, partisans, Basan Gorodovikov, Mokrousov, Crimean Tatars

For citation: Polyakov V. E. The Crimean Period in the Life of Basan Gorodovikov. Oriental Studies. 2021. Vol. 14 (3): 469-478. (In Russ.). DOI: 10.22162/2619-0990-2021-55-3-469-478
\end{abstract}

\section{है}

\section{Введение}

В яркой и насыщенной биографии крупного военного и политического деятеля Калмыкии, Героя Советского Союза Басана Бадьминовича Городовикова период его пребывания в Крыму с августа 1941 г. по июнь 1942 г. является одним из самых драматичных. К сожалению, эта часть в его биографии относится к одному из самых крупных «белых пятен», а имеющаяся историография по данному вопросу насыщена разного рода мифами и только запутывает читателя [Городовиков 1960; Шамко 1976; и др.].

\section{Материалы и методы}

Данная статья основана на широком круге документальных материалов, выявленных в Государственном архиве Республики Крым, а также мемуаров участников партизанского движения. В ходе работы использовался широкий спектр исследовательских методов - как общенаучных (объективность, синтез, историзм), так и 
специальных исторических (историко-генетический, историко-сравнительный, историко-системный). Например, при изучении действий крымских партизан сведения из архивных документов сопоставлялись с воспоминаниями участников событий, что позволило выявить ряд неточностей в описании истории тех событий.

\section{В Крымских горах \\ В обороне Крыма}

В начале войны 30-летний Басан Бадьминович Городовиков, только что закончивший Военно-воздушную академию командного и штурманского состава, был произведен в подполковники и вернулся в родной род войск - кавалерию. Он был назначен командиром вновь сформированного 71-го кавалерийского полка (далее - кп) 48-й кавалерийской дивизии (далее - кд), которую в августе 1941 г. передислоцировали в Крым. Здесь для защиты полуострова формировалась 51-я Отдельная армия, в которую вошли: 106, 156, 172, 184, 271, 276, 320, 321-я стрелковые дивизии (далее - сд), 40, 42 и 48-я кд. Фактически 4 стрелковые дивизии из 8 являлись ополчением, причем частично даже не имели вооружения; 2 стрелковые дивизии и 3 кавалерийские дивизии были только сформированы [Басов 1987: 34, 37-38; Исаев и др. 2016: 5, 8].

К сожалению, Ставка Верховного Главнокомандующего и командующий 51-й армии генерал-полковник Ф. И. Кузнецов по неизвестным нам причинам опасались угрозы высадки в Крыму воздушного или морского десанта, для которых на тот момент вермахт не имел реальных возможностей. Вместо того чтобы усилить наиболее реальное для прорыва в Крым перекопское направление, они разместили имеющиеся дивизии по всему периметру Крыма. 48-я кд под руководством генерал-майора Д. И. Аверкина находилась в центре полуострова, являясь резервом командующего.

24 сентября противник начал штурм Перекопского перешейка, который защищала только 156-я сд, но лишь 30 сентября из Москвы поступил приказ: «все силы - на крымские перешейки». Батов с горечью писал в своих мемуарах: «Если бы эти слова были сказаны месяц назад» [Батов 1984: 90]. Тогда же в его воспоминаниях впервые упоминается 48-я кд, которая занималась подготовкой противотанковых препятствий вдоль русла реки Чатырлык. В чис- ле ее офицеров он назвал и подполковника Б. Б. Городовикова, взвод из полка которого успешно провел разведку позиций противника [Батов 1984: 98].

18 октября 11-я армия Э. фон Манштейна начала новое наступление на Перекопском перешейке. Комиссар 48-й кд Е. А. Попов впоследствии вспоминал, что соединение вступило в бой в пешем строю 19 октября под Ишунью и вскоре потеряло почти половину состава из 2900 человек [ГАРК. Ф. П-151. Оп. 1. Д. 17. Л. 32].

Сам Басан Городовиков в своем письме к дяде - генерал-инспектору кавалерии Красной армии О. И. Городовикову об этих боях вспоминал так: «Впервые полк (71) вступил в бой с врагом 19 октября 1941 года в самый критический период, когда враг захватил Перекоп, Армянск, Ишунь. Полк сражался героически, выдержал 8 дневных атак с танками и 4 ночных... Полк удерживал противника в течение 9 дней. Я сам был три раза ранен, мне было предложено уйти. Я оставался до тех пор, пока не было приказано всей 48 кд отойти, и 29 октября наша дивизия отошла. Надо сказать, 48 кд дралась так, что если бы все так дрались, Крым бы мы никогда не отдали» (цит. по: [Балакаев 1995: 17]).

На помощь 51-й армии была переброшена Приморская армия, эвакуированная из Одессы. Однако 28 октября Манштейн прорвал фронт [Исаев и др. 2016: 27].

Немецкие войска устремились к Керчи и Севастополю. Когда катастрофа оборонявших Крым войск стала свершившимся фактом, остатки 156, 271 и 157-й сд начали отступать к Керчи. Туда же со второстепенных участков отходили 106-я, 276-я и 320-я сд. Прибывшая из Одессы Приморская армия и влившиеся в нее 172-я сд, 40-я и 42-я кд стали отходить на Севастополь. Остальные дивизии (421-я сд из Одессы, 184-я сд и 48-я кд) отступили к горным перевалам, по направлению к Алуште. Там якобы их ждали специально направленные суда. Однако никаких кораблей в порту не оказалось. Эти соединения почти трое суток отражали атаки противника, но затем были вынуждены пойти на прорыв из образовавшейся ловушки. Положение окруженных серьезно затрудняли ухудшившиеся погодные условия: с 5 ноября в Крыму начались снегопады и морозы.

Остатки 48-й кд попытались прорваться в сторону Судака для того, чтобы затем уйти 
на Керчь, но успеха не достигли и были вынуждены уйти в горы. Во время перехода пропал начдив - генерал Д. И. Аверкин. Как выяснилось впоследствии, он, не поставив в известность своего начальника штаба М. Т. Лобова, с небольшой группой бойцов и командиров пошел в сторону Севастополя. Не зная, что случилось с начдивом, его сутки разыскивали, а затем кавалеристы стали пробиваться в Карасубазарские леса, где только 10 ноября они встретились с партизанами 2-го района [Партизанское движение 2006: 181].

\section{У истоков формирования партизан-} ского движения Крыма

Следует пояснить, что организация партизанского движения в Крыму имела свою специфику. Поскольку считалось, что Крым оккупирован не будет, его организацией здесь первоначально не занимались. Только 22 октября, когда катастрофа на Перекопе стала очевидной, были назначены руководители партизанского движения Крыма: командующим - А. В. Мокроусов (командующий истребительными батальонами Крыма), комиссаром - С. В. Мартынов (1-й секретарь Симферопольского горкома ВКП(б). 23 октября приступили к созданию партизанских отрядов. Между тем до вступления немецко-румынских войск в Симферополь оставалась неделя.

При этом партизанские отряды стали формировать не на базе населения горно-лесной местности, а из партийно-советского актива всего Крыма, включая степные районы. Весь горно-лесной массив Крыма был условно разбит на пять районов. В Карасубазарских лесах развернулся 2-й партизанский район (командир - И. Г. Генов), в который входили Биюк-Онларский, Джанкойский, Зуйский, Ичкинский, Карасубазарский, Колайский и Сейтлерский партизанские отряды, созданные на базе партийно-советского актива одноименных районов. Предполагалось, что партизанская эпопея продлится не более трех месяцев, потому в лес шли с женами и даже с детьми. В результате этого среди партизан района оказалось 208 женщин и даже 8 детей [Генов 1983: 58].

Вместо того чтобы укрепить свои семь отрядов прибывшими опытными военнослужащими, И. Г. Генов сформировал из них три самостоятельных так называемых красноармейских отряда по 100-120 чело- век в каждом [Партизанское движение 2006: 84]. Комиссар 48-й кд Е. А. Попов был назначен комиссаром района. Подполковник Б. Б. Городовиков возглавил 1-й Красноармейский отряд, созданный из остатков его полка. Этот отряд сразу начал проводить боевые операции: 10 ноября участвовал в бою под Молбаем, 13 ноября - в налете на Верхний Кокасан, 14 ноября - в налете на Нижний Кокасан [ЦАМО. Ф. 43. Оп. 11536. Д. 41. Л. 270].

Вскоре от стихийно сложившихся названий отказались, и все крымские отряды официально получили единую нумерацию. 1-й Красноармейский отряд стал называться 15-м партизанским. Следует заметить, что красноармейские отряды, в отличие от местных, не имели запасов продовольствия, а делиться с ними никто не стал. Мало того, ряд имеющихся продовольственных баз оказался захвачен противником, в результате чего в некоторых отрядах начался голод. К тому же суровая зима наступила очень рано. Поэтому красноармейские отряды были вынуждены вести активные действия и добывать запасы в окрестных селах [ГАРК. Ф. П-151. ОП. 1. Д. 17. Л. 32].

В приказе № 21 командующий партизанским движением Крыма отмечал, что «многие отряды, потерявшие свои продбазы, находятся в условиях полуголодного существования, несмотря на то, что продукты этих отрядов разграбили местные жители, у которых можно легко изъять эти продукты и жить сытной жизнью. Однако некоторые начальники $\mathrm{p}$ [айо]нов не делают этого, боясь заходить в деревню, хотя в этих деревнях нет противника и вооруженных банд. Примером этой болезни боязни может служить начальник 5-го района т. Красников и некоторые отряды 3 и 4 районов. Наряду с этим мы имеем много случаев проявления подлинных партизанских действий. Так, например, командир отряда 3-го р[айо]на т. Городовиков не имел баз, но он сумел отобрать у жителей награбленное на базах других отрядов и теперь обеспечен продовольствием; командир Ичкинского отряда т. Чуб потерял свои базы и теперь так же, как и т. Городовиков, отобрал награбленное и живет великолепно. Тт. Городовиков и Чуб не только отобрали у жителей наши продукты, а выбили из нескольких деревень вооруженные отряды и теперь живут в населенных пунктах, пользуясь поддержкой жителей» [Партизанское движение 2006: 42-43]. 
Отряд Б. Б. Городовикова в течение двух с половиной месяцев располагался в селах Айлянма, Чермалык, Бешуй [ГАРК. Ф. П-151. Оп. 1. Д. 17. Л. 34]. Первые попытки выбить партизан силами отрядов самообороны из сел успеха не имели. 18 декабря отряд Б. Б. Городовикова в бою уничтожил 12 «карателей» [Партизанское движение 2006: 38]. 20 декабря Айлянма была атакована отрядом румын. После захвата села каратели расстреляли 18 местных жителей за связь с партизанами [Книга Памяти 1995: 140].

Достаточно активно действовали и другие красноармейские отряды, например, отряд капитана И. Г. Куракова, который занял с. Сартана. Спустя много месяцев после этого новый командующий партизанским движением Крыма, анализируя эти события, подчеркнул, что «Благодаря этому 2-й район получил дополнительные продукты, в частности в большом количестве было получено картофеля. Можно сказать, что 2-й район в этот период примерно до апреля был обеспечен продовольствием» [Партизанское движение 2006: 157]. При этом 1-й район, который таких акций не проводил, уже к 15 февраля «лишился своих баз и перешел на иждивение 2-го района» [Партизанское движение 2006: 157]. Об активности красноармейских отрядов писал и И. Г. Генов в донесении от 20 февраля 1942 г.: «Отряды $15,17,18$ сумели пополнить свои продбазы за счет враждебного населения» [ГАРК. Ф. П-151. Оп. 1. Д. 13. Л. 33].

Фраза «враждебное население» требует пояснения. Дело в том, что систематические набеги партизан на близлежащие села, сопровождавшиеся насильственным изъятием скота, продуктов питания, вызвали конфликт с партийно-советским активом других отрядов, многие из которых были жителями этих районов. Командующий партизанским движением А. В. Мокроусов в данном конфликте поддержал «военных», поскольку оценивал эти действия как боевую активность, в то время как другие отряды, у которых еще было продовольствие, по его мнению, «только отсиживались в лесу». Конфликт с местным населением был умело использован оккупантами. В горных селах разрешили создавать отряды самообороны и носить стрелковое оружие в пределах своего села. В ряде сел компактно проживали болгары, греки, татары, значительная часть которых не владела русским языком. Все это создало стену недопонимания, недоверия, а затем и открытой враждебности между партизанами и населением. Не разбираясь в национальной мозаике полуострова, «военные» всех жителей горного Крыма считали «татарами», что и породило миф о массовом предательстве крымских татар. В какой-то степени эта версия была удобной и партизанскому руководству, которое теперь могло заявить, что против партизан выступает не всё население горного Крыма, а лишь только татары. Понимая несправедливость таких «продовольственных операций», партизаны в отчетах стали использовать выражения типа «забрали корову у брата старосты» [ГАРК. Ф. П-151. Оп. 1. Д. 414. Л. 32].

Первые месяцы немецко-румынские войска были прикованы к осажденному Севастополю, поэтому партизаны чувствовали себя относительно безопасно. С началом Керченско-Феодосийской десантной операции партизаны через армейских разведчиков установили радиосвязь с командованием фронта и начали проводить акции в интересах Крымского фронта. Уже 29 декабря партизанские отряды № 10 и 15 в ходе налета на вражескую колонну уничтожили 3 грузовых автомашины и 64 человека, большинство из которых оказались офицерами. По предположению И. Г. Генова и Е. А. Попова, эта колонна была каким-то штабом жандармерии или гестапо, бегущим из Феодосии, занятой советским десантом [Партизанское движение 2006: 38]. 3 января 1942 г. отряд № 15 произвел налет на с. Капырликой, 7 января - устроил засаду на дороге Карасу - Феодосия, 19-20 января на дороге Судак - Суук-Су. Одновременно партизаны Б. Б. Городовикова активно вели разведку в интересах Крымского фронта, уничтожали линии связи. Только по данным на 1 февраля, «городовиковцы» в ходе 23 акций вырезали 3200 метров кабеля [ЦАМО. Ф. 43. ОП. 11536. Д. 41. Л. 271].

20 февраля 1942 г. 5 отрядов 2-го района (Джанкойский, Карасубазарский, Ичкинский и красноармейские - Б. Б. Городовикова и И. Г. Куракова) при поддержке авиации Крымского фронта отразили атаку карательных отрядов противника в районе гор Аю-Кая и Берлюк. 


\section{Конфликт}

В конце января 1942 г. в Карасубазарские леса прорвались остатки Судакского десанта под командованием майора Н. Г. Селихова. На их базе были сформированы 1-й и 4-й Красноармейские отряды. Руководство Крымским фронтом, установив с ними связь, стало сбрасывать на парашютах продовольствие, которое предназначалось только для «селиховцев». Подобная нелепица была обусловлена тем, что командование фронта имело право отпускать продовольствие находящимся в окружении своим частям, но партизанам, подчинявшимся другой инстанции, передавать его было нельзя. Если раньше «местные» отказывали «военным» в передаче продуктов питания, то теперь сложилась противоположная ситуация: продуктами снабжали только «военных». Конфликт между «военными» и «местными» обострился еще больше, но приобрел новый вектор. Если раньше А. В. Мокроусов был на стороне «военных», то теперь стал выступать против них. Однако с установлением радиосвязи «военные» получили мощную поддержку от командования Крымского фронта. Был отстранен от своей должности командир 2-го района И. Г. Генов, которого сменил майор Н. Г. Селихов - командир 226-го горнострелкового полка из Судакского десанта.

Конфликт обострился до предела, когда А. В. Мокроусов расстрелял командира партизанского отряда капитана Алдарова. Комиссар 2-го района Е. А. Попов (бывший комиссар 48-й кд) в одном из своих докладов охарактеризовал А. В. Мокроусова, как «выжившего из ума старика», а в другом докладе подчеркивал: «Мокроусов вместо того, чтобы целиком опереться на знания, умения и силы военных, создал условия бойкота руководящего состава воинских частей. Мокроусов и Мартынов считают, что военные, пришедшие в лес, уже не военные и в связи с этим запрещалось бойцам и командирам говорить о своих частях. Мокроусов ненавидит командиров из 48 кд за их сплоченность. Неоднократно Мокроусов в пьяном виде, в присутствии многих кричал: „Эти паршивые полковники“, „паршивой 48-й дивизии“... Желая разобщить командный состав дивизии, он распорядился отправить отряд Городовикова в Бахчисарайские леса на голодную смерть, и только Ваше вмешательство помешало этому» [ГАРК. Ф. 1. Оп. 1. Д. 17. Л. 34, 93, 94].
Несмотря на конфликт в руководстве, партизанские отряды продолжали свои акции против оккупантов. 11 марта отряд Б. Б. Городовикова произвел налет на д. Орталан, а 14 марта отразил вражескую атаку на Айлянму, записав на свой счет 85 солдат противника. Кроме того, 15-й отряд осуществлял походы в район партизанских аэродромов для получения грузов для военных. Всего к концу марта отряд Б. Б. Городовикова уничтожил 247 чел. и 10 автомашин, в ходе 27 акций вырезал 3750 м кабеля, взорвал мост [ЦАМО. Ф. 43. Оп. 11536. Д. 41. Л. 272].

Следует заметить, что Басан Городовиков обладал не только хорошими командными качествами, но имел и отличную индивидуальную подготовку, был снайпером. Бывший танкист 48-й кд и пулеметчик 15-го отряда Э. М. Грабовецкий вспоминал, что однажды в Карасубазарских лесах во время перехода к горе Средней отряд Б. Б. Городовикова попал в засаду. «Каратели» начали наступать на залегших партизан, но «вот тут и выручили нас его верный глаз и руки. За несколько минут он снял один за другим шесть фашистов. Этого было достаточно, чтобы они бежали» (цит. по: [Балакаев 1995: 15]).

Заслуги Басана Городовикова были по достоинству оценены командованием. 7 апреля 1942 г. командующий Крымским фронтом генерал-лейтенант Д. Т. Козлов приказом № 0463 наградил 3 партизан из числа «военных» орденом Красного Знамени и 4 - орденом Красной Звезды [ЦАМО. Ф. 33. ОП. 682524. Д. 608. Л. 156]. Первым в этом списке значился Б. Б. Городовиков. Впрочем, он об этом даже не знал, как и о склоке в руководстве партизанским движением Крыма, начавшейся по вопросу награждений.

Еще в феврале 1942 г. с установлением воздушного моста, из привезенных газет в Крыму узнали о щедром награждении партизан Керчи (зимой 1941 г. заблокированных в каменоломнях), явно несоответствующем их подлинной деятельности. На этом фоне «лесные» крымские партизаны, которые за три месяца оккупации провели десятки реальных боев с противником, выглядели куда более предпочтительно. Командующий партизанским движением А. В. Мокроусов послал представление на награждение 67 партизан, наиболее отличившихся на его взгляд. «Военные», которых в этом списке 
не оказалось, послали свое представление. Крымский обком ВКП(б) в лице его первого секретаря В. С. Булатова принял сторону А. В. Мокроусова, командование Крымского фронта - сторону «военных».

Началась война компроматов: «На Ваше письмо от 5.03.42 о представлении к ордену Ленина командира партизанского движения Крыма полковника Лобова Михаила Тихоновича и комиссара партизанского движения полкового комиссара Попова Ефима Абрамовича сообщаю: С первых дней прибытия в район действий партизанских отрядов Лобов и Попов начали противопоставлять себя командованию, внося раздор между военными и гражданскими товарищами. С этой целью группировали вокруг себя командиров частей РККА, попавших в партизаны из вражеского окружения и вообще недовольных, обиженных, снятых с командных постов за те или иные поступки.

Затеянная склока Поповым и Лобовым привела к обострению до крайности взаимоотношений между командирами и отразилась на боевой деятельности партизанских отрядов в тот период.

Лобов и Попов за время пребывания в партизанах в боевых делах ничем себя не проявили, больше того, Лобов систематически пьянствовал.

Категорически возражаю и прошу Вас к награде их не представлять.

Уполномоченный штаба в/ч 00125 Булатов» [ГАРК. Ф. П-151. Оп. 1. Д. 199. Л. 101].

В результате этого вопрос о награждении М. Т. Лобова, Е. А. Попова и некоторых «военных», так же как А. В. Мокроусова и его протеже, «завис в воздухе». Лишь семеро крымских партизан из числа «военных» были награждены вышеупомянутым приказом командования Крымского фронта.

21 апреля 1942 г. было создано Главное командование Северо-Кавказского направления, которое возглавил маршал С. М. Буденный. Первоначально главком решил отложить вопрос о награждениях до окончательного освобождения Крыма. После поражения немецких войск под Москвой, Ростовом и Тихвином, первоначального успеха Керченско-Феодосийской десантной операции освобождение Крыма казалось вопросом ближайшего будущего. Однако в мае 1942 г. 11-я армия Э. фон Манштейна разгромила Крымский фронт, сбросив его остатки в море. Командующий партизан- ским движением А. В. Мокроусов, наряду с руководством Крымского фронта, был отнесен к виновникам этого поражения. 19 мая 1942 г. Главное командование Северо-Кавказского направления было упразднено, а на базе его управления сформировали управление Северо-Кавказского фронта.

По мере того как маршал вникал в положение дел в Крыму, его отношение к А. В. Мокроусову стало заметно ухудшаться, в итоге в конфликте в руководстве партизанского движения Крыма главком принял сторону «военных». Например, в докладной И. В. Сталину маршал С. М. Буденный и адмирал И. С. Исаков писали: «Неприязнь Мокроусова к военным товарищам дошла до того, что он начал буквально третировать и издеваться над такими командирами, как полковник Лобов, назначенный начальником главного штаба партизан, полковым комиссаром Поповым, которого Мокроусов после назначения его военкомом 2-го партизанского района арестовал; полковника Городовикова, который своей храбростью и смелыми боевыми операциями в тылу противника снискал себе всеобщее уважение и любовь всех партизан» [ГАРК. Ф. П-151. Оп. 1. Д. 17. Л. 15]. На постановлении бюро Крымского обкома ВКП(б) за подписью В. С. Булатова от 15 июля 1942 г. по отчету о деятельности партизанских отрядов Крыма с ноября 1941 г. С. М. Буденный начертал такую резолюцию: «Все это выдуманная ложь, так как партизан Крыма не было и нет, есть остатки воинских частей, которые действуют партизанскими методами. Мокроусов и обком (Булатов) принимают все меры, чтобы разложить эти остатки воинских частей» [Партизанское движение 2006: 95].

В июле 1942 г. маршал С. М. Буденный добился отзыва командующего А. В. Мокроусова и комиссара С. В. Мартынова на «большую землю» и назначил на их место полковника М. Т. Лобова (бывшего начальника штаба 48-й кд) и находившегося в оппозиции к А. В. Мокроусову секретаря Зуйского райкома партии, комиссара Зуйского отряда Лугового. Таким образом, вся власть в партизанском Крыму сосредоточилась в руках «военных».

Следует подчеркнуть, что Б. Б. Городовиков не участвовал в этих склоках. И в рапортах «военных» (фактически его сослуживцев по 48-й кд), и в рапортах «местных» во главе с Булатовым его отряд неизмен- 
но перечислялся в числе лучших. Неудивительно, что Басан Городовиков в числе первых был награжден орденом Красного Знамени. 26 апреля ему присвоили звание полковника, а 27 апреля - назначили командиром 1-го партизанского района (Старо-Крымские леса). Согласно документам, Б. Б. Городовиков руководил этим районом до 30 мая, но фактически это назначение осталось «на бумаге»: в Старо-Крымских лесах он никогда не был.

\section{Эвакуация}

Разгром Крымского фронта привел к серьезным переменам в судьбе Б. Б. Городовикова. Дело в том, что он являлся родственником крупного советского военачальника - генерал-инспектора кавалерии Красной армии Оки Городовикова. После пленения Якова Джугашвили, факт которого активно использовался в нацистской пропаганде, угроза захвата в плен (в отличие от гибели в бою) родственников высокопоставленных лиц государства стала серьезным политическим вопросом. Весной 1942 г., когда перспективы освобождения Крыма казались весьма близкими, вероятность возможного пленения Б. Б. Городовикова была низкой. Однако после разгрома Крымского фронта этот вопрос заметно актуализировался. Следует заметить, что маршал С. М. Буденный был одностаничником О. И. Городовикова, с которым служил и дружил еще со времен Гражданской войны. Поэтому в начале июня 1942 г. командованием Северо-Кавказского фронта было принято решение об эвакуации Б. Б. Городовикова на «большую землю».

Для эвакуации маршал приказал выбрать лучшего летчика из числа летавших ранее к крымским партизанам. Командующий 4-й воздушной армией генерал-майор К. А. Вершинин выбрал для этой операции летчика 764-го ночного бомбардировочного авиаполка лейтенанта И. И. Молчанова, который до этого летал с Керченского полуострова к партизанам и чудом вышел из окружения. Маршал С. М. Буденный лично поставил задачу молодому летчику.

И. И. Молчанову на выбор предоставили два самолета С-1 (санитарная версия У-2), но у обоих аэропланов оказались очень слабые моторы. Раньше он летал к партизанам с Керченского полуострова, но теперь предстояло лететь через море с Кубани, что для C-1 было весьма сложной задачей. Однако приказ надо было выполнять, несмотря ни на что. По рации партизанам дали указание о подготовке сигнальных костров. После начала вылета И. И. Молчанов у мыса Чауда почувствовал в кабине запах бензина и повернул обратно. На аэродроме в станице Славянской техники обнаружили трещину в трубке бензопровода: самолет только чудом не загорелся в воздухе. Тем не менее командарм К. А. Вершинин, отругав за невыполненное задание, приказал пилоту вылетать вновь. Не отдохнув, И. И. Молчанов вновь взял курс на Крым. На высоте 1500 м он вышел к маяку на мысе Меганом, но при приближении к хребту самолет стремительно потянуло вниз, на высоту около 1000 м, что было заметно ниже горных вершин. И. И. Молчанов еще два раза пытался пересечь хребет в других местах, но самолет, словно магнитом, тянуло вниз. Короткая июньская ночь заканчивалась, пришлось возвращаться в Славянскую.

Командарм был весьма раздражен невыполнением задания и еще сильнее отругал молодого пилота. На следующую ночь И. И. Молчанов взял другой С-1. После долгого полета над морем пилот вдруг обнаружил, что компас неисправен, а когда приземлился, то оказался в Майкопе. Во время вылета в третью ночь в полете почувствовал себя очень плохо и повернул назад. Врач, услышав жалобы летчика на «огоньки перед глазами», отправил его отсыпаться.

Наутро из Краснодара пригнали капитально отремонтированный С-2 с более мощным мотором. Благодаря этому вылет в ночь на 15 июня наконец оказался успешным. И. И. Молчанов смог перевалить через горы, заметил сигнальные костры на Орта-Сырте и посадил машину на партизанском аэродроме. Летчика узнали, стали радостно «качать». Партизаны уже хотели приступить к погрузке раненых, но И. И. Молчанов твердо заявил, что имеет приказ вывезти в первую очередь Б. Б. Городовикова. Поскольку командир отряда был в лагере в нескольких километрах от аэродрома, то пришлось за ним послать гонца. Через некоторое время Басан Городовиков пришел в сопровождении двух партизан, которые помогали ему идти [Емельяненко 1998: 196].

Здесь необходимо сделать небольшое отступление. В течение нескольких лет автор вел и ведет прием граждан из числа крымских татар, которые приносят доку- 
менты своих отцов, дедов - участников Великой Отечественной войны. Среди них была Эмине Велишаева - дочь Сеит-Али Велишаева. До войны он был членом бюро обкома комсомола, возглавлял пионерскую организацию Крыма. В 1941 г. Сеит-Али служил в полку Б. Б. Городовикова политруком, а в партизанском отряде был рядовым бойцом, кстати, единственным из числа крымских татар. Оказалось, что именно он вместе с Василием Олейниковым сопровождал, фактически нес обессилевшего от голода Б. Б. Городовикова из лагеря к аэродрому.

После освобождения Крыма С.-А. Велишаев разделил судьбу своего народа, был депортирован в Узбекистан, не смог восстановиться в партии, так как в партизанских скитаниях потерял партийный билет. По прошествии лет он узнал из газет, что его командир отряда стал «большим человеком»: Герой Советского Союза, генерал, первый секретарь Калмыцкого обкома КПСС. Сеит-Али написал ему письмо, где напомнил о своей службе, о том, как с В. Олейниковым нес Б. Б. Городовикова на аэродром, и попросил рекомендацию для восстановления в партии. Первый секретарь тут же ответил теплым дружеским письмом, в самых лучших словах отозвался о боевом прошлом С.-А. Велишаева и прислал официально заверенную рекомендацию на восстановление в партии. Вторую рекомендацию прислал бывший командир отряда Куликовский, который к тому времени был начальником милиции в Феодосии и хорошо помнил своего товарища по партизанскому прошлому. Благодаря таким рекомендациям С.-А. Велишаева восстановили в партии и подобрали должность, соответствующую его опыту. Б. Б. Городовиков и С.-А. Велишаев до конца своих дней поздравляли друг друга с праздниками, обменивались короткими письмами, в которых Б. Б. Городовиков по-стариковски сетовал на плохое здоровье, врачей, которые ничего не понимают. В их письмах совершенно не чувствовалась разделявшая их социальная пропасть. Это была переписка двух боевых товарищей [ЛАА].

Вернемся в 1942 год. По прилете в станицу Славянская И. И. Молчанов позвонил в штаб воздушной армии, доложил о выполненном задании и получил приказ лететь в Краснодар. Там их встретил инженер-полковник Руденко, который усадил обоих в легковой «ЗИС-101» и сказал летчику:
«Тебе вместе с Городовиковым будут ордена вручать... А то ведь над тобой, брат, уже трибунал висел» [Емельяненко 1998: 197].

Отряд, которым до своего отлета на «большую землю» командовал Басан Городовиков, официально стал носить его имя. 24 октября 1942 г. был издан приказ № 018 командующего Черноморской группой войск Закавказского фронта генерал-лейтенанта И. Е. Петрова о награждении 288 крымских партизан: 6 - орденами Ленина, 112 - Красного Знамени, 109 Красной Звезды, 29 - медалью «За отвагу», 25 - медалью «За боевые заслуги», 25 - «Партизану Отечественной войны» 1-й степ. [Поляков 2009: 106-110]. Среди них было 20 бойцов и командиров из отряда имени Б. Б. Городовикова: 7 чел. получили орден Красного Знамени, 8 - орден Красной Звезды, 4 - медаль «За отвагу», 1 - медаль «За боевые заслуги» [Брошеван 2001: 47].

\section{Заключение}

Крымский период был самым драматичным в жизни Басана Городовикова. Здесь он пережил отступление, бои в окружении, голод, стал невольным участником конфликта «военных» и партийно-советской элиты в партизанском движении Крыма.

Поскольку историю пишут победители, а Крымский обком ВКП(б) уже в 1944 г. монополизировал все, что было связано с оценкой партизанского движения в Крыму, имена «военных» из числа старших командиров 48-й кд, ставшей ядром партизанского движения в Зуйских лесах, подвергались либо шельмованию, либо забвению. Есть в Симферополе школа имени А. В. Мокроусова, улицы А. В. Мокроусова, И. Г. Генова, многих других партизан, но нет ни одной улицы, названной в память командиров-партизан из числа «военных». Писать о конфликте в крымском партизанском сообществе в 1942 г. считалось моветоном. Только в последние годы в музейных экспозициях стали появляться фотографии М. Т. Лобова, Е. А. Попова, Б. Б. Городовикова... Время идет. Оценки меняются.

Почти сразу после войны знаменитый украинский партизан П. П. Вершигора издал книгу «Люди с чистой совестью», которую посвятил своим прославленным соратникам из соединения С. А. Ковпака. На мой взгляд, эти слова можно однозначно сказать и о Басане Бадьминовиче Городовикове. 


\section{Источники}

ГАРК - Государственный архив Республики Крым.

ЛАА - Личный архив автора.

ЦАМО - Центральный архив Министерства обороны РФ.

\section{Литература}

Балакаев 1995 - Балакаев А. Г. Народный генерал. Элиста: РИП «Ботхн», 1995. 400 с.

Басов 1987 - Басов А. В. Крым в Великой Отечественной войне 1941-1945 гг. М.: Наука, 1987. 336 с.

Батов 1984 - Батов П. И. В походах и боях. 4-е изд. М.: ДОСААФ, 1984. 511 с.

Брошеван 2001 - Брошеван В. М. Крымский штаб партизанского движения: Хроника в документах и материалах. Симферополь: [б. и.], 2001. $101 \mathrm{c.}$

Генов 1983 - Генов И. Г. Дневник партизана. Симферополь: Крымиздат, 1983. 279 с.

Городовиков 1960 - Городовиков О. И. Мой племянник Басанг // Наши земляки - Герои Советского Союза. Элиста: Калм. кн. изд-во, 1960. C. 25-27.

\section{References}

Balakaev A. G. The People's General. Elista: Botkhn, 1995. 400 p. (In Russ.)

Basov A. V. Crimea in the Great Patriotic War, 1941-1945. Moscow: Nauka. 1987. 336 p. (In Russ.)

Batov P. I. In Military Campaigns and Battles. $4^{\text {th }}$ ed. Moscow: DOSAAF, 1970. 170 p. (In Russ.)

Broshevan V. M. Crimean Headquarters of the Partisan Movement: The Chronicle in Documents and Materials. Simferopol, 2001. 101 p. (In Russ.)

Emelianenko V. B. Air Bridge - Rescue in the Dark. Moscow: Sovetskaya Rossiya, 1985. 352 p. (In Russ.)

Genov I. G. Diary of a Partisan. Simferopol: Krymizdat, 1983. 279 p. (In Russ.)

Gorodovikov O. I. My nephew Basang. In: Our Fellow Countrymen - Heroes of the Soviet

\section{Sources}

Ministry of Defense of the Russian Federation. Central Archives.

State Archive of the Republic of Crimea.

Personal archives of the author.

Емельяненко 1998 - Емельяненко В. Б. Воздушный мост - спасение во тьме. М.: Сов. Россия, 1998. 352 с.

Исаев и др. 2016 - Исаев А., Глухарев Н., Романько О., Хазанов Д. Битва за Крым 1941-1944. М.: Эксмо; Яуза, 2016. 896 с.

Книга Памяти 1995 - Книга Памяти Республики Крым. Т. 6. Партизаны и подпольщики. Симферополь: Таврида, 1995. 271 с.

Партизанское движение 2006 - Партизанское движение в Крыму (1941-42). Симферополь: COHAT, 2006. 244 c.

Поляков 2009 - Поляков B. E. Награждение крымских партизан в 1941-1945 гг. // Культура народов Причерноморья. 2009. № 154. С. 106-110.

Шамко 1976 - Шамко Е. Н. Дорогами крымских партизан. Симферополь: Таврия, 1976. 114 с.

Union. Elista: Kalmizdat, 1960. Pp. 25-27. (In Russ.)

Isaev A., Glukharev N., Romanko O., Khazanov D. The Battle for Crimea, 1941-1944. Moscow: Eksmo; Yauza, 2016. 896 p. (In Russ.)

Memorial Book of the Republic of Crimea. Vol. 6: Partisans and Resistance Fighters. Simferopol: Tavrida, 1995. 271 p. (In Russ.)

Polyakov V. E. Awards for Crimean partisans, 1941-1945. Culture of the Peoples of the Black Sea Region. 2009. No. 154. Pp. 106-110. (In Russ.)

Rybina O. V. (ed.) Partisan Movement in Crimea, 1941-1942. Simferopol: SONAT, 2006. 244 p. (In Russ.)

Shamko E. N. Following the Routes of Crimean Partisans. Simferopol: Tavriya, 1976. 114 p. (In Russ.) 